\title{
Ellipsis
}

2017

\section{Life After the Cinders}

Siera E. Martinez

University of New Orleans

Follow this and additional works at: https://scholarworks.uno.edu/ellipsis

\section{Recommended Citation}

Martinez, Siera E. (2017) "Life After the Cinders," Ellipsis: Vol. 44 , Article 29.

DOI: https://doi.org/10.46428/ejail.44.29

Available at: https://scholarworks.uno.edu/ellipsis/vol44/iss1/29

This Fiction is brought to you for free and open access by the Department of English and Foreign Languages at ScholarWorks@UNO. It has been accepted for inclusion in Ellipsis by an authorized editor of ScholarWorks@UNO. For more information, please contact scholarworks@uno.edu. 


\section{Life After the Cinders}

Siera Martinez

Cyndra Perrault wasn't always repulsed by her husband. She used to be happy in her marriage. She used to love him.

During the earlier stages of her marriage, she used to go out to the fine, stimulating gardens and fountains of her new home, Perrault Manor. Though she hated animals, she made it a habit to feed pumpkin seeds to the cotton rats and ravens that wandered around the fountains. This was a meditative habit for Cyndra as she thought about how blessed she was to be married to Charlie. He had money. He loved her; she loved him. But by the grace of God, he had money. And because of it, she would never struggle again. She was so grateful for how her life had played out (though she was barely twenty-four) that when Charlie's strange fetish began to break the surface of her tranquility, she faced it with a humble heart.

She was quite charmed, at first, of the Louboutins he'd lavish her with. Those chic, black, patent leather pumps, stark against the succulent red bottoms, made slick by the skinny heels, drove Charlie to follow her around the mansion like a dog. She liked this attention, and so did her feet. They had never tasted genuine leather before. They had never walked upon such exquisite soles before. Each time Charlie opened a new box of Louboutins to present to his wife, the air was filled with the refined scent of leather which reassured her soul; she would never so much as walk on anything less than the very best.

Christian Louboutin was followed by Manolo Blahnik, Jimmy Choo, Coco Chanel, and when Charlie came across a pair of transparent Marc Jacobs pumps he had an epiphany. This epiphany is what troubled Cyndra.

"Cyndra." He walked in breathless, carrying boxes that stacked up to his chin. Boxes that were gold with scrawly cursive imprinted on the tops, boxes that were tied with silk ribbons, boxes that Cyndra couldn't have afforded without Charlie. His seagreen eyes were brightened and his brown curls seemed as excited as he was as they bounced around with his animated steps. "Sit down on that ottoman, will you?" He set the boxes down as she sat.

"More shoes..."

"You have never seen these." he said, white teeth gleaming in a princely smile. Cyndra couldn't help but roll her eyes.

"You say that about every new pair of shoes, Charles." Her voice had that rare, smooth drip of southern moonlit drawl. That same drawl that commanded Charlie to watch the way her mouth moved when she spoke, the drawl that could force anyone to pay attention to her.

As he slipped on the clear pumps (not before pressing a kiss on the top of her foot just as any southern gentleman would press a kiss on a lady's hand), he became fascinated by the way her white foot was made to glow by the transparent vinyl material. 
"Are you happy now, Mr. Perrault?" she said with a raised brow, coyness in her voice. She looked down at the shoes her feet occupied and found that they were quite nice despite being transparent. Transparent pumps reminded her of strippers from the sixties, but these pumps didn't evoke tackiness.

"More than happy." There was a silence as he looked her feet over. "My little metaphors."

"What?"

"Your feet, my loves - my love, they're a metaphor, you see, for how magnificent and life-altering they are. They'll be legendary." This wasn't the first time she had heard of "The Metaphor" that Charlie occasionally muttered under his breath. Previously, he would deny he muttered anything when questioned about it. These days, he acknowledged it when he said it. Still, he never bothered to explain "The Metaphor" in intelligible detail and because of that, she wasn't quite sure if he genuinely understood what the hell he was talking about. Eyes speculative, she stared at him.

And then ignored him, because she wasn't sure she wanted to understand.

Despite her attempt at ignorance, in this moment, she felt something heavy and foreboding in her chest, like her veins were trying to pump peanut butter. But she was grateful. She had money. She had security. She was grateful.

When Cyndra became pregnant, she blamed Christian Louboutin for the Summer Collection of 2015, Iriza in Blush No 1.

Charlie was happy as could be, though it took Cyndra some time to accept that she was going to have a baby. She worried about being a mother because she never had much experience with her own. Her mother was a fading image of black hair and cardboard eyes, nothing more.

When she voiced her concerns about being a parent to Charlie one night over dinner, the conversation hastened toward the gloomy fact that Cyndra didn't grow up in a traditional household.

"But I thought you had sisters?" Charlie sipped his Sazerac.

Cyndra nodded, her mud brown eyes lowered briefly before flicking upwards, as if she remembered that she could want for absolutely nothing; a notion from where she constantly drew power. "I had two sisters, but they were witches." She stabbed her salmon with a silver fork that glittered under the chandeliers and candlelight.

Charlie hid a smile at his wife's inability to murmur an expletive. He never asked about her sisters again.

When Cyndra couldn't dye her hair platinum blonde anymore, problems started to arise. Charlie was irritated when he found out Cyndra wasn't a real blonde. Why he thought that platinum blonde was a natural color, Cyndra would never know. However, he was seething when her feet began to grow.

"What do you mean they don't fit you!" he looked at her bewildered, a gold heel dangling from his index finger.

"Charlie, dear, please calm down... You know a woman's feet get bigger when she's carrying a baby. The doctor explained that to us just the other day. Weren't you paying any attention?" 
"Is this permanent!" Cyndra had never seen him with this look. As if he had just witnessed a kitten getting run over by a truck. But, that look of horror mutated into something much more severe. Vitriol revved into those green irises as if someone had floored the gas. Cyndra could have sworn they bordered on radioactive. She couldn't for one minute convince herself that the source of such poison was due to the trivial fact that her feet had grown half a size.

She removed herself from the room and began a marathon of nervous cleaning, a habit Charlie had tried to break her out of before. Cyndra dusted everything in the entire manor. She had been at it for the entire morning and lost track of time as the sun began to set. Cleaning at Perrault Manor wasn't easy for how gaudily ornate it was; in fact, it took a weekly visit from a cleaning crew for to sustain its impeccable upkeep. As Cyndra dusted the library, her heart rate began to lower, tranquility settled in.

With her delicate touch, she dusted the broken grandfather clock in the living room. It was an antique that had stopped working and Charlie had wanted to throw it away. But Cyndra always dusted and polished its elaborate carvings just as if she herself had crafted and carved the clock. She always loved clocks because time was not only abstract, but evasive, and the physical structure that was a clock seemed to capture time, to freeze it. The day it stopped working was the day she moved in to Perrault Manor.

When the night fell in, Cyndra slipped into a scalding bath.

"Relaxin," Charlie said as he entered the master bath, eyes cast down to the screen of his phone, "is the chemical that women release when they are pregnant." Cyndra looked at him cooly with eyes colored like spiced cinnamon under the dim light of the bathroom. She was so put off by his reaction earlier that just the sight of him made her feel like she was in an ice bath.

Charlie took a seat on the step of the porcelain tub, unaware of the expression on her face. With aromatic bubbles up to her neck, she chose not to acknowledge him; still he continued, eyes on his phone, "This chemical softens up some of the ligaments in a woman's body to prepare her for birth. This is why your feet have gotten bigger, my ember. Just slightly. And yes, it is permanent, just in case you were wondering." Charlie's voice was soft, as if trying to console her from a tragedy.

Cyndra stared at him. No, I hadn't been wondering, because I don't give a-ham. Her mind wondered at what it would be like to escape from Charlie and drown in her own bath, or better, what it would be like to hold him under for a few minutes. He was still talking about feet and growing sick from it.

"And just what are you going on about, Charlie?" she said agitatedly. She scrubbed her hands with a soap made from plantain ashes to try and keep her brain from convincing her heart to pull Charlie down under.

"I'm saying it's not your fault." his eyes were like grass that was being tousled by the wind, velvety. And it was the genuine expression in his eyes that made her angry. "It's okay. We'll just have to buy you more shoes."

As the months rolled by, Charlie's obsession subsided. His outburst never crossed Cyndra's mind again. She may have forgotten it because she began to enjoy her husband and the prospect of motherhood as a woman should - peacefully. Charlie was like a real husband to her again; he got excited when he'd use his hands to feel around for the baby. He'd sing little songs to Cyndra's belly, and the child inside yielded to its father's voice. 
Cyndra too, despite the aches and pains that came with pregnancy, was ecstatic whenever she felt her child move. One morning, her stomach began to intermittently give off gentle jolts of movement.

"Charlie!" she yelled. And he came running into the kitchen with a toothbrush sticking out of his mouth and a towel wrapped around his waist. He was dripping wet and there were still soap suds in his curly hair.

"What is it!" he said with wide eyes, his mind jumping to the worst possible outcomes.

Cyndra's black hair glistened with the movements of her sonorous laughter. "I think the baby has hiccups! Look, come and feel." It was a blissful moment, and Cyndra couldn't fathom how she had ever been repulsed by Charlie to begin with.

He was hopelessly charmed by the idea of a baby having hiccups in his mother's womb, transported even, and she was hopelessly charmed by his already growing, fatherly love.

When it came time for one of the ultrasounds, Charlie was eager to know what the baby was going to be. At the last ultrasound they were unable to find out because the baby had been in a position where its sex was not determinable.

"Alright, let's see if we can get this baby to spill its secrets," said the technician. "What are you hoping for, Momma? And don't you dare tell me you just want it to be healthy. Because everybody knows that's just the polite answer."

"I really want a boy." Cyndra said it as if she asked a question. She looked at Charlie who she caught staring at her.

"And you, Daddy?" the technician asked of Charlie.

"I want a girl," he said without hesitation.

The ultrasound was of no use. The baby still wouldn't tell if it was a boy or a girl. But this didn't bother Charlie.

"It's a girl," he said on the drive back home.

"You can't possibly know that." Cyndra said to him, arching her brow. She leaned back on the seat and closed her eyes as she put a hand over her round belly.

"I do too know that." Charlie leaned over and kissed her cheek, putting a hand possessively on her knee.

Cyndra opened one eye to look at him before closing it. There was a familiar look of determination brewing in his eyes, something that made her feel uneasy about the way he furrowed his brows.

The following day, Charlie burst into the grand doors of his manor with a princely smile. "Cyndra!" he called out to her.

"I'm in the living room!" she answered. He entered the room, carrying a healthy stack of small boxes.

He opened one of the boxes and took out what looked like a miniature Mary Jane. A baby bootie. With a red bottom.

"What on earth, Charlie! Is that_-" the color drained from Cyndra's face as she looked at the shoe.

"Baby Louboutins, for our precious little girl."

She stared wide-eyed at the baby booty. They weren't even sure of the sex yet, and here Charlie was buying shoes for the girl that might not be. Her heart battered 
against her chest. Her surroundings seemed to her like a photograph that was overexposed - she couldn't make out the lines of objects, she couldn't find anything concrete to focus her eyes on. Overwhelmed, she tried to stand. She looked down at Charlie who was kneeling before her with the tiny shoe in his palm.

Her voice quivered with counterfeit strength, "There is something so unsound about-"

As if she hadn't spoken at all, Charlie went on, "And look at these little Chanel booties," he said, holding them up so Cyndra could see, "she won't be able to fit into these right away, but that's alright, she can start wearing the Louboutin ones instantly. I was able to get these custom-made so we can slip them on as soon as she pops out."

Cyndra's heartbeats and breaths drummed tribally in her ears. A sacrifice was about to be made.

She started again, searching for her voice, "Charles, we need to-" she was cut off yet again by another shoe Charlie was dangling in front of her face. Shoes, baby shoes everywhere, the scent of leather potent, invading her lungs. Her hands grew cold with the shocking realization that she couldn't give a child to this man; she couldn't be married to this man. This man was not a real man. With her body under stress she began to feel the onset of a twitching pressure in her lower belly.

She needed to calm down, it wasn't good for the baby. "Charles!" before she could complete her thought the broken clock, the clock that had stood still and frozen for so many months, the clock that Cyndra took care to polish and dust every week, began to alarm the house that it was noon. 